\title{
導電性アルミナ系セラミックスの放電加工特性
}

\author{
顔 炳 華 蔡 徳 昌
}

台湾国立中央大学機械系

J. Japan Inst. Metals, Vol. 58, No. 12 (1994), pp. 1467-1472

\section{Electrical Discharge Machining Characteristics of Conductive Alumina Based Ceramics}

\author{
Biing Hwa Yan and Der Chun Tsai \\ Department of Mechanical Engineering, National Central University, Taiwan, ROC
}

\begin{abstract}
In order to reveal the electrical discharge machining characteristics of electrical conductive alumina based ceramics, a series of EDM tests are carried out. The following main results are obtained. (1) The surface roughness of ceramics machined with negative polarity is larger than that with positive polarity. (2) When machining ceramics with small current, compared with positive polarity, the material removal rate of negative polarity is larger and the electrode wear ratio is smaller. But when machining with large current, the relation is reversed. (3) When machining with short pulse and negative polarity, the recast layer is thinner and almost no crack is observed because of the impact force caused between the workpiece and electrode is larger than positive polarity. (4) Compared with normal EDM, material removal rate machined with orbital motion of an electrode is higher, but the surface roughness and the electrode wear ratio are worse. But when the orbital distance of an electrode increases, the surface roughness and the electrode wear ratio are improved remarkably.
\end{abstract}

(Received August 23, 1993)

Keywords: electrical conductive alumina based ceramics, electrical discharge machining, polarity, material removal rate, electrode wear ratio

\section{I. 緒言}

セラミックス材料が高硬度, 高耐摩耗, 高強度叔よび高耐熱 性という長所があるため, 非常に苛酷な環境下でも利用できる が, その反面, 硬脆性材料に属し, 通常の機械的加工法では加 工性が悪く, ダイヤモンド工具を用いる以外, ほとんど加工不 能といってもよい欠点がある. そのため, 機械部品としての応 用は加工可能な形状の制約や加工コストの増加が大きな問題と なっている. しかし, 最近, 耐摩耗性, 耐食性掞よび耐熱性の 機械部品やプラスチック射出成形用型材としてセラミックスの 使用が多くなっているので, 容易な加工技術の確立が望をれて いる.

放電加工は高エネルギー密度を利用し，材料の機械的性質に ほとんど影響されない加工法であるため，セラミックス材料の 加工法として期待されている. しかし，これに関する研究報 告(1)-(4) はまだ十分とは言えない。そこで本報では, 型彫放電 加工機を用い, TiCを添加した導電性アルミナ系セラミック スを対象材として異なる極性の放電加工実験を行い, 加工速 度, 加工面めらさ, 電極消耗率および表面変質層などの観点か らセラミックスの放電加工特性について検討した. また, 加工 特性の改善に有効であるといわれる電極を摇動しながらの放電 加工法(5)(6)をも行い, セラミックスの放電加工特性に対する影 響について調べた.

\section{II. 供試材料および実験方法}

実験に供した加工材料は $12 \mathrm{~mm} \times 4 \mathrm{~mm} \times 12 \mathrm{~mm}$ に仕上げ た市販されている 30 mass\%の TiC を添加した導電性アルミ ナ系セラミックスである. Table 1 にその材料の機械的㧊よび 物理的性質を示す．また，工具電極は底面寸法 $3 \mathrm{~mm} \times 12$ $\mathrm{mm}$ に仕上げた電解銅である. 実験はトランジスタ制御付コン デンサ放電回路の型彫放電加工機を用いて Fig. 1 に示すよう に，被加工材と工具電極を直交させて行った。また，一部の実 験では工具電極を被加工物に対し，摇動しながらの放電加工を も行った．な拉，加工液は通常のケロシンである．実験条件は Table 2 に示す.

Table 1 Physical and mechanical properties of test material.

\begin{tabular}{l|c}
\hline \hline Melting point $(\mathrm{K})$ & 2473 \\
Density $\left(\mathrm{kg} / \mathrm{m}^{3}\right)$ & 3980 \\
Thermal conductivity $(\mathrm{W} / \mathrm{m} \cdot \mathrm{K})$ & 21 \\
Electrical resistivity $\left(10^{-2} / \Omega \cdot \mathrm{m}\right)$ & $10^{2}$ \\
Tension strength $(\mathrm{MPa})$ & 882 \\
Hardness $(\mathrm{mHV})$ & 3000 \\
\hline
\end{tabular}




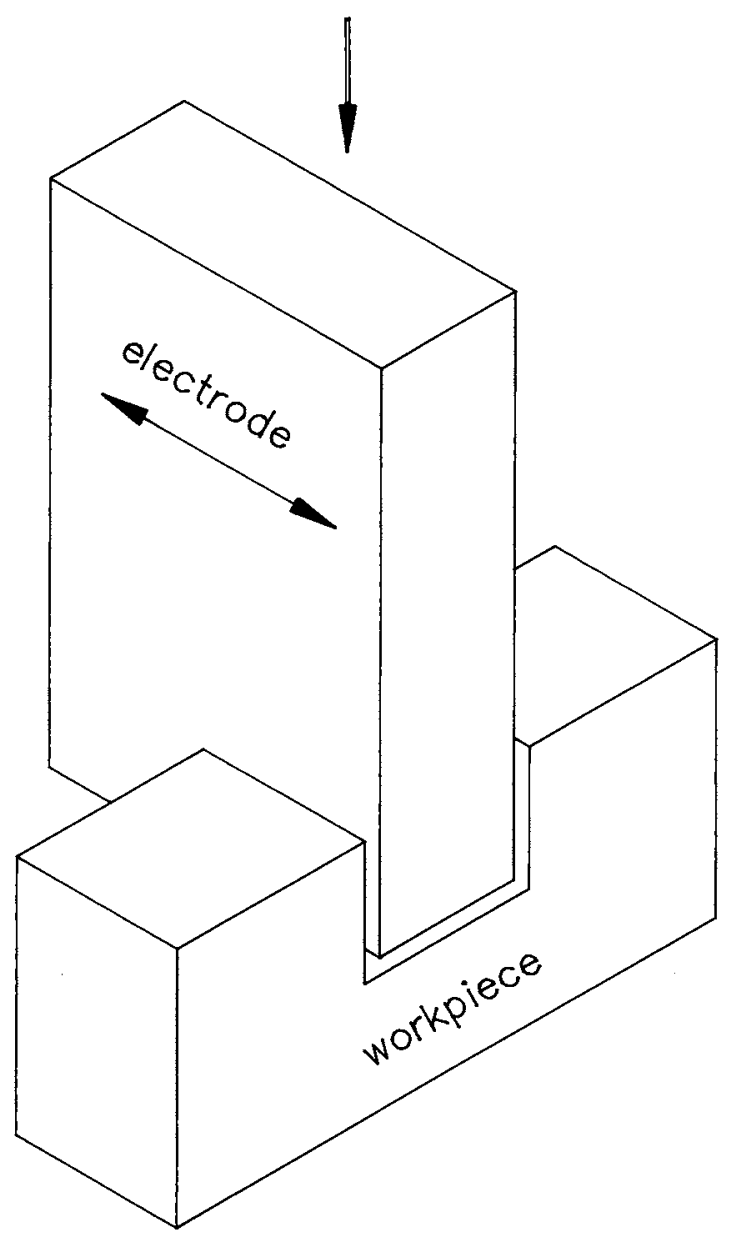

Fig. 1 Schematic orbit motion of electrode.

Table 2 Electrical discharge machining conditions.

\begin{tabular}{l|l}
\hline \hline \multicolumn{1}{c|}{ Work condition } & \multicolumn{1}{c}{ Work parameter } \\
\hline Workpiece & Ceramics $\left(\mathrm{Al}_{2} \mathrm{O}_{3}+\right.$ mass30\% TiC $)$ \\
Electrode & $\mathrm{Cu}$ \\
Workpiece size $(\mathrm{mm})$ & $12^{1} \times 12^{\mathrm{w}} \times 4^{\mathrm{t}}$ \\
Electrode size $(\mathrm{mm})$ & $40^{1} \times 12^{\mathrm{w}} \times 3^{\mathrm{t}}$ \\
Polarity & positive and negative \\
Voltage $(\mathrm{V})$ & 90 \\
Peak current $(\mathrm{A})$ & $0.2 \sim 6$ \\
Pulse duration $(\mu \mathrm{s})$ & $5 \sim 300$ \\
Duty factor & Automatic control \\
Dielectric & Kerosene \\
Dielectric flow rate $(1 / \mathrm{h})$ & 6 \\
Orbit motion mode & Linear motion $(0,0.5,1.0,1.5 \mathrm{~mm})$ \\
Work time $(\mathrm{S})$ & $9 \times 10^{2}$ \\
\hline
\end{tabular}

\section{III. 実験結果および考察}

\section{1. セラミックスの放電加工特性に対する極性の影響}

金属材料の放電加工では, 工具電極を陽極, 被加工物を陰極 にする屰極性加工, および工具電極を陰極, 被加工物を陽極に する正極性加工は極間に供給するエネルギーの配分が異な る(7)(8) と言われ，放電加工特性の相違が生じる。これに関する
研究がすでにいくつか報告されだ(9)-(11)．しかし，金属材料と 比べ，融点，熱伝導率拉よび比低抗率などの物理的珄質がかな り異なるセラミックス材料の放電加工では，極性による影響が いまだに不明な点が多いそこで，まず TiC 添加の導電性ア

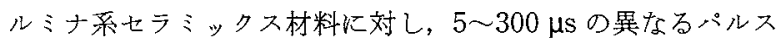
幅，3 A の放電電流で放電したとき，正，逆極性加工に上る表 面あらさへの影響について調べた．Fig. 2 は放電加工後の表 面あらさの比較を示す。図から，逆極性加工の表面あらさが正 極性加工のものよりも大きいことが加かる。李た，逆極性加工 の表面方らさがパルス幅の増加に伴って急激に悪化する傾向以 対し，正極性加工の場合では，パルス幅による影響が此較的に 小さくなっていることがわかる。

な特，同一放電条件で，正，逆極性放電加工後のセラミック スの表面状態を一例として Fig. 3 亿示す。図より逆極性放電 加工の表面泣状の再凝固物が多く付着しているのに対し，正 極性加工の方は再凝固物が少なく，比較的平滑な表面となって いる。このような原因は主として逆極性放電加工時, 陰極に乙 たセラミックス表面の放電点のエネルギー密度がより高く, 十 分な加工熱で表面を比較的大さな溶融規模で除去できるが，こ れに対し，正極性放電加工の場合ではェネルギー密度が比較的 に小さいため，融点の高いセラミックスを大規模に溶融でき ず，表面が比較的平滑な状態となる．また，図に示すように， いずれの極性加工に括いても，放電加工面上に多くの空孔之刍 裂が存在する。特に正極性加工の場合では，パルス幅の増大に 伴って亀裂が多くなることも確認された。

一方，異なる放電条件で放電したときの加工速度について調 ベてみると，Fig. 4(a)，(b)飞示すよらに，いずれの極性に蛙 いても放電電流の增加にしたがって加工速度が大きくなる。ま た, $0.2 \mathrm{~A}$ の微小電流の放電加工 (a)では, 逆極性放電の加工 速度が正極性の放電より大きくなっているが，6A 電流で放電 加工(b)すると，逆極性放電加工の方が反対に小さくなる。こ の理由は次の上うに考完られる。すなわち，微小電流で放電す ると，放電エネルギーが小さく，融点の高いせラミックスをエ ネルギー密度の低い正極性放電加工で加工すると，材料が徽小 規模でしか除去できない，そのため，エネルギー密度の高い逆 極性放電加工上り加工速度が小さくなる．ところが，金属材料 と異なり，七ラミックスが硬くて脆い材料であるため，放電加

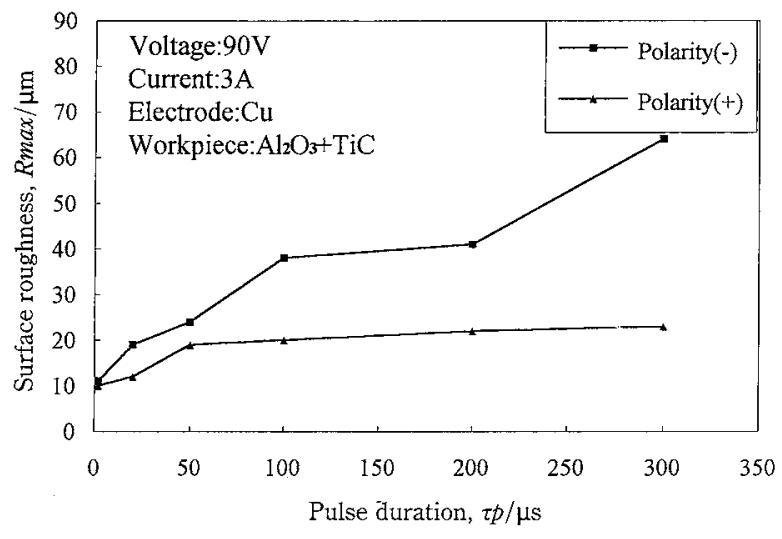

Fig. 2 Effect of polarity on the surface roughness of electrical conductive ceramics. 


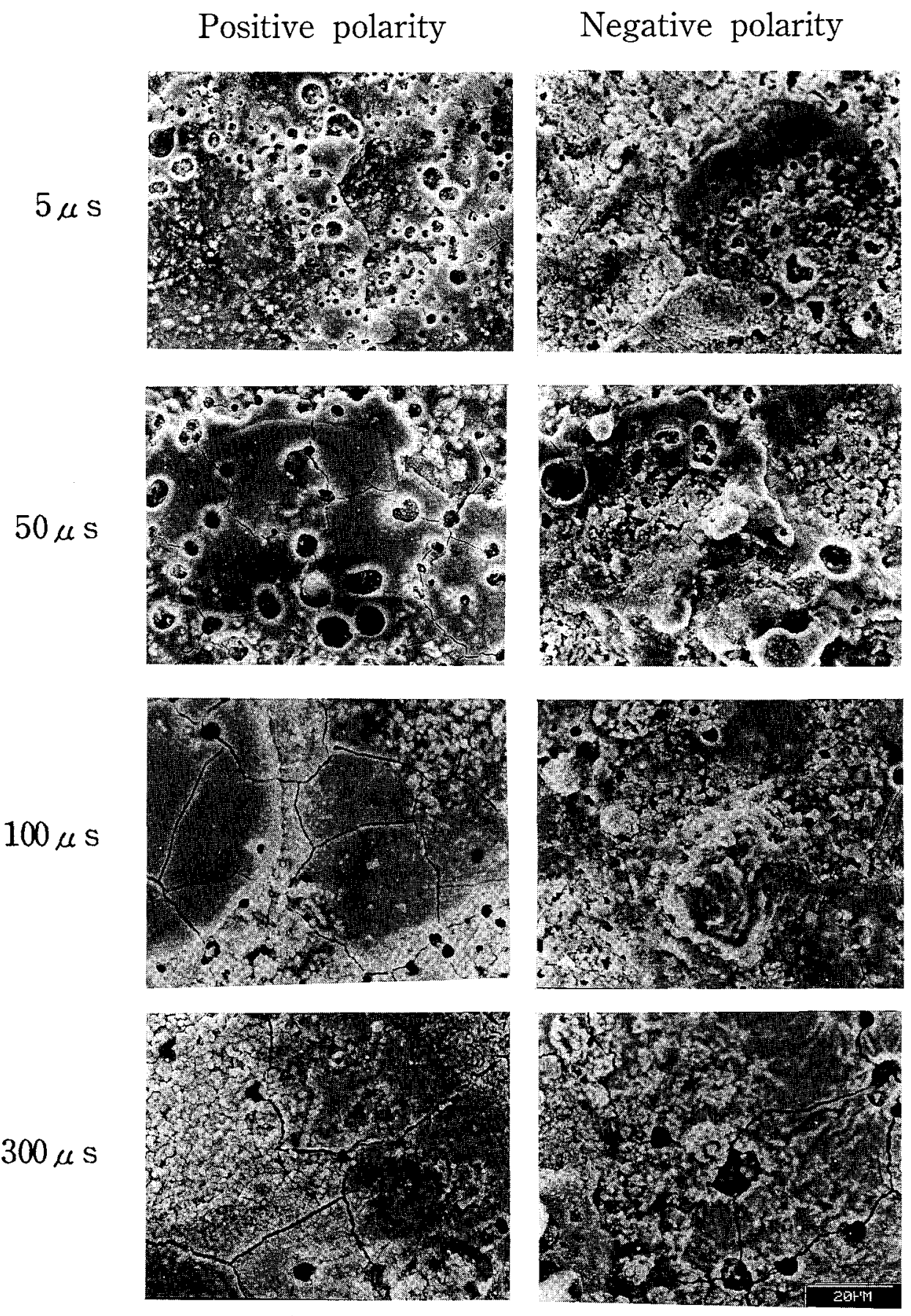

Fig. 3 Micrographs of work surface of electrical conductive ceramics after machining in different conditions. $\left(I_{\mathrm{p}}=3 \mathrm{~A}, \tau_{\mathrm{p}}=5 \sim 300 \mu \mathrm{s}\right)$

エのような熱作用による加工法では，表面の除去が溶融だけに よるのではなく、急熱・急冷による熱応力で表面渑裂が生じて 材料を除去されること考光られる．6-Aのような比較的大き な電流を用いて，かつエ采ルギー密度の高い逆極性放電加工で 加工寸ると, 亀裂迈材料除去の比率が大きくなり, 加工屑 の形状子通常の金属放電加工のよう火球状ではなく，破片状の すのが多くなり，狭い極間からの排除が一層困難となる，々の ため，正極性放電加工に比べ，放電が不安定となり，加工速度
の低下をもたらすと思われる。

な和，6Aの電流を用いて放電加工するとき，いずれの極性 に执いても，パルス幅が極小のとき，加工速度がかなり小さい が，パルス幅の増加にしたがって加工速度が急増し，あるパル ス幅で最高值となる。乙かし，ハルス幅がさらに増加すると加 工速度がかえって遅くなる。この理由はSinghら (12)の推論に よると，パルス幅が極小のとき，極間に供給された土ネルギー の大部分が絶縁破壊に消耗されたので，実際に材料の溶融消 

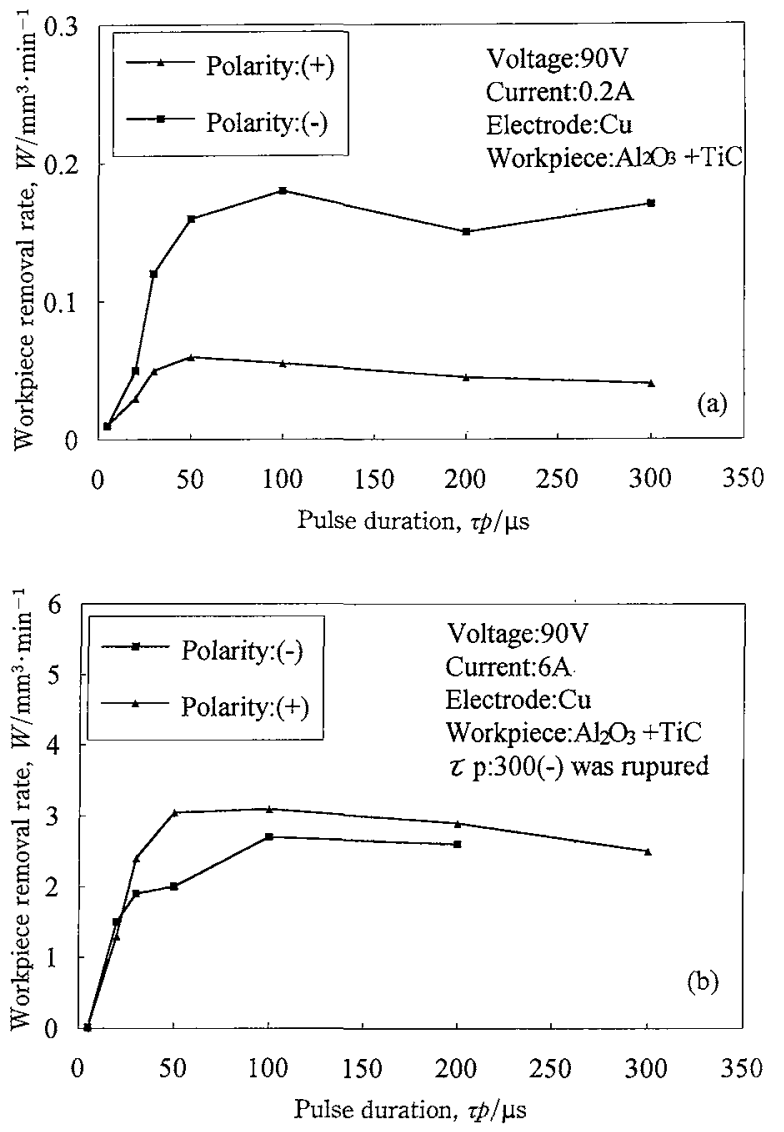

Fig. 4 Effect of polarity on workpiece removal rate of electrical conductive ceramics.

(a) $I_{\mathrm{p}}=0.2 \mathrm{~A}$, (b) $I_{\mathrm{p}}=6 \mathrm{~A}$

耗されたエネルギー量が少ない，そのため，加工速度がかなり 小さい.一方, パルス幅值の增加にしたがい, 蒸発と溶融が安 定的な平衡状態を保ち，加工速度も增大する傾向となる。した がって，各供給ェネルギーに批て最高の加工速度を得るため には，適当なパルス幅が存在するはずである，勿論，パルス幅 が大き過ぎると，溶融層が厚く，李た放電点の拡大によるエネ ルギー密度が低下して十分な爆発力で除去できず，凹凸の激し い再凝固層となり，そのため，加工速度を低下させることも重 要な原因と考学られる。

な括，一発の放電エネルギーの大きさがほぼ放電電流之パル 又幅の積に比例するので，放電加工面を形成するとき，休止時 間と放電電流を一定にしても，パルス幅の増加にしたがって放 電エネルギーが増大し，セラミックス表面の刍裂発生の規模も 大さくなり，遂に巨大な破裂が生じ，大さな破片が極間に残留 することもしばしばある，そのため，放電加工の進行に悪影響 を及法す，また，場合に上って放電不能な状態となる可能性も ある. Fig. 4(b) に逆極性加工の曲線がパルス幅 $200 \mu \mathrm{s}$ 以上の 部分を示さなかったのはこの理由によるものである.

一方，極性による電極消耗率の影響に関してはFig.5(a)， (b) K示すように，小電流放電の場合 (a)では, 逆極性加工の 万は電極消耗率が小さいが，6A の電流で放電すると(b)，正 極性加工の方が小さい，また，いずれの極性に招いても放電 パ
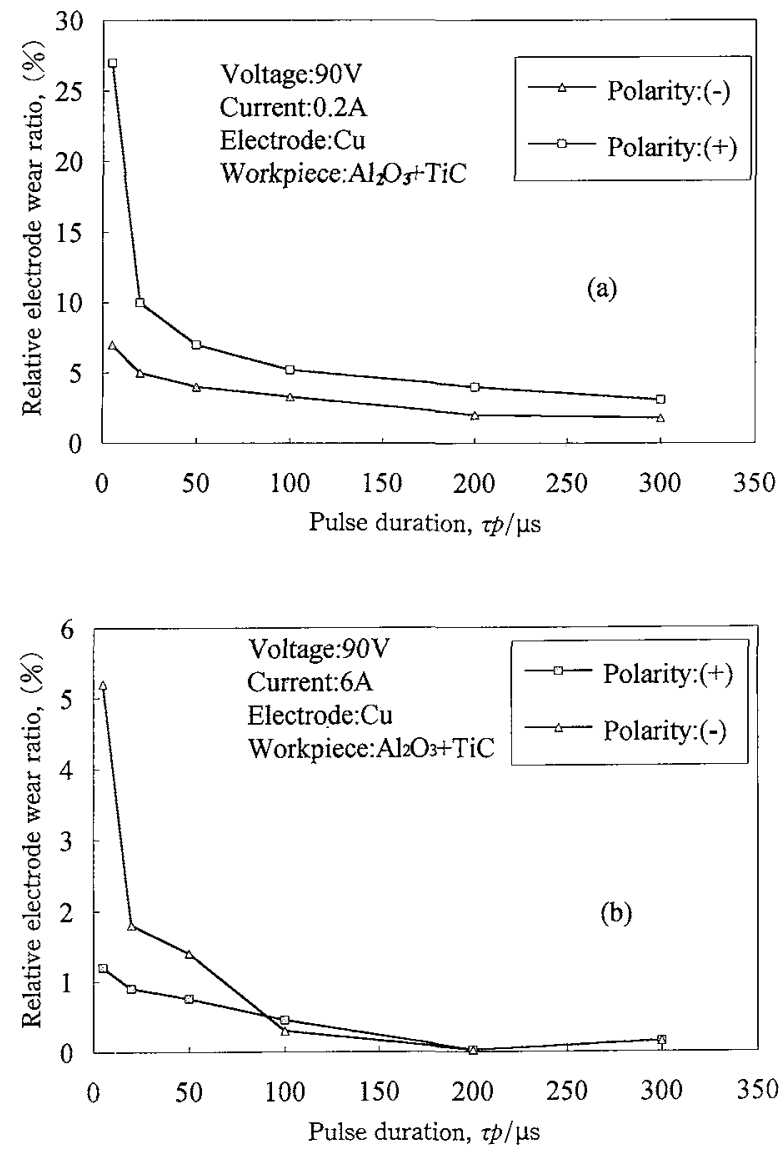

Fig. 5 Effect of polarity on relative electrode wear ratio of electrical conductive ceramics.

(a) $I_{\mathrm{p}}=0.2 \mathrm{~A}$, (b) $I_{\mathrm{p}}=6 \mathrm{~A}$

ルス幅の增加に伴って電極消耗率が小さくなるが，パス幅 $\tau_{\mathrm{p}}=100 \mu \mathrm{s}$ 以上になると，その差が汪とんど認められない。

\section{2. セラミックス放電の材料除去機構}

前述の上うに, セラミックス材料の放電加工時, 放電加工面 上に微細な龟裂と空孔が多く生じることが観察された。このよ らなことは主としてセラミックスの放電加工面上に数 $\mu \mathrm{s}$ 数

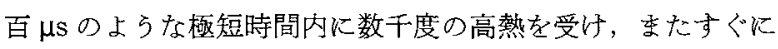
急冷され，熱応力が生じて表面に引張応力，その内部に圧縮応 力を生じたためである。これらの微細渑裂が主として再凝固層 の表面に生じたが，放電ェネルギーの状態によって表面からあ る程度の深さまで伝播する。また，場合によって，Fig. 6(a)k示すように，これらの龟裂が連結してミク口的破填と なることも観察されたすすなわ，通常の金属材料の放電と異 なり，七ラミックスを放電加工した場合，材料の除去機構は放 電柱で生じた衝撃力による溶融材の除去だけではなく，蒸発に よる空孔の生成执よび集裂云播の連結によるミク口的破壊が材 料除去速度を促進させるるのと考光られる。乙かし，放る放電 エネルギー以上になると，象裂が大き過ぎ，簡単に連結するた め,、ク口的破壊となることもしばしばあると思わ秃る。 Fig. 6(b)拉よび Fig. 6(c)飞示すように，表面の一部が大きな 破片として除去され，加工面が悪化し，遂に放電不能な状態と 
a)

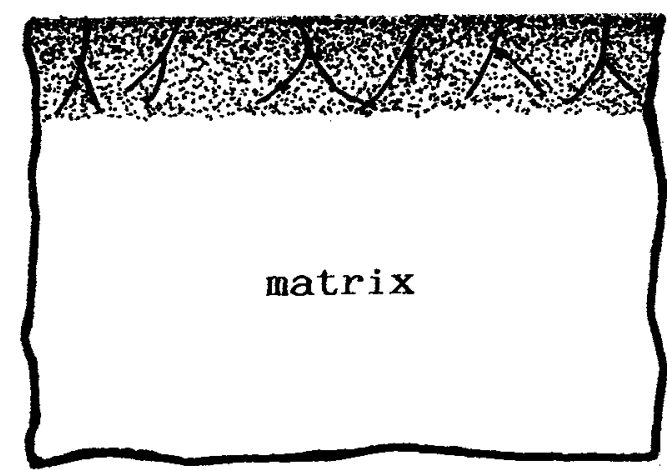

b)

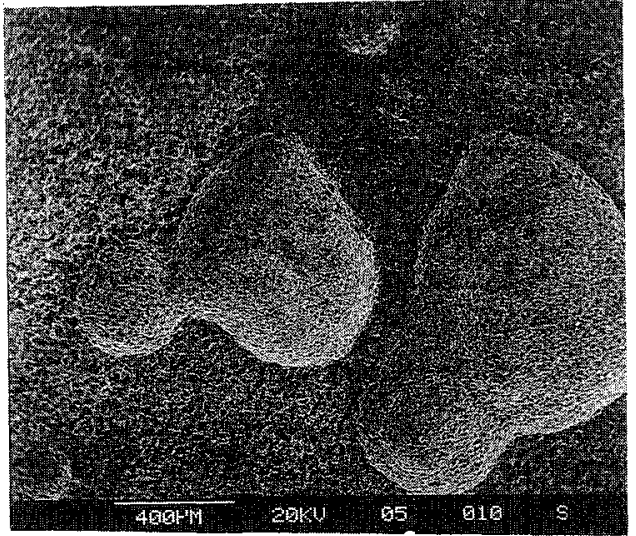

c)

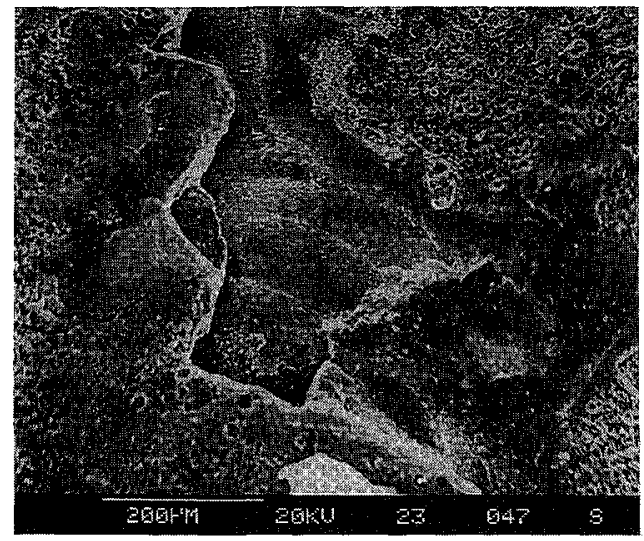

Fig. 6 Typical fractured surfce of electrical conductive ceramics when machining in negative polarity. $\left(I_{\mathrm{p}}=6 \mathrm{~A}, \tau_{\mathrm{p}}=300 \mu \mathrm{s}\right)$

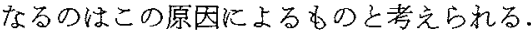

ところが, Fig. 7(a)，(b)に示すように，電流 $I_{\mathrm{p}}=3 \mathrm{~A}$, ㅇ ルス幅 $\tau_{\mathrm{p}}=20 \mu \mathrm{s}$ の条件を用いて正, 逆極性で放電したセラミ ックス試片の断面状熊からわかるように，逆極性放電の場合 (b)，再凝固層がほとんどなく，亀裂む見当たらないのに対 し，正極性放電の力(a)性再凝固層が厚く残留し，また，その 中に微細亀裂が影著に存在することが確認された，その理由は Fig. 8 K示す放電時の極間に生じた衝撃力から推測できる. すなわち，小パルスでの逆極性放電の場合, 工作物上の放電痕

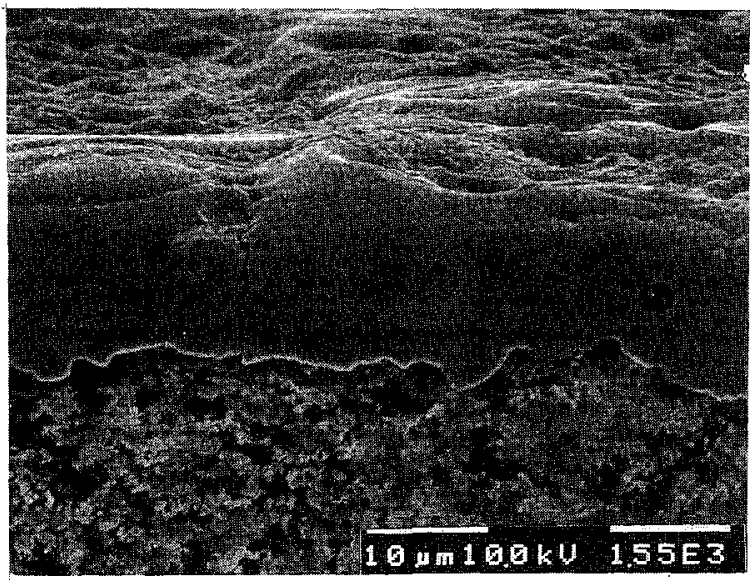

(a) Postive polarity

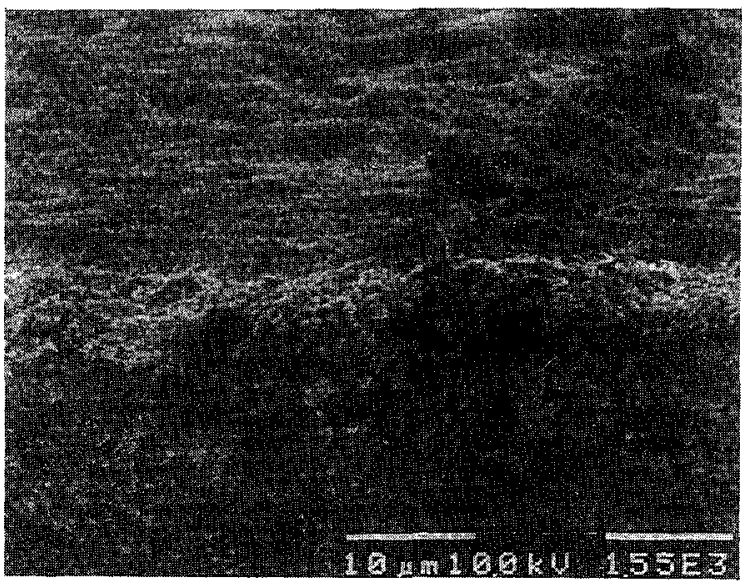

(b) Negative polarity

Fig. 7 Effect of polarity on the cross section microstructures of electrical conductive ceramics. $\left(I_{\mathrm{p}}=3 \mathrm{~A}, \tau_{\mathrm{p}}=20 \mu \mathrm{s}\right)$

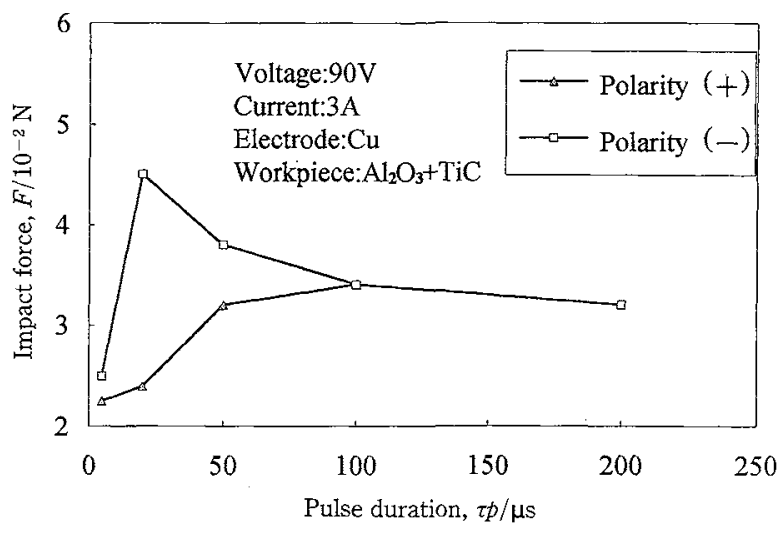

Fig. 8 Effect of polarity on the impact force.

の大きさが比較的に小さく，エネルギー密度が高いため，大き な衝撃力で薄い:溶融層（金属材料に比べ，七ラミックスの熱伝 
導率がかなり低いため，溶融層が薄い)を完全に除去すること ができるのに対し，正極性放電の場合，十分な衝撃力がなく， 溶融層の一部が再凝固層として残留すると考兄られる．ただ し，パルス幅が大きくなるにしたがって逆極性加工の衝撃力が 急速に低下するため，その効果が少なくなる．な拉，この場合 に示した衝撃力が単発放電のときに生じた瞬時圧力ではなく, 連続放電しながら，一定のサンプリングタイムで検出した衝撃 力の平均值である. Fig. 8 亿示すように，高くても $4.5 \times 10^{-2}$ N しかないが，セラミックスの熱伝導性が非常に悪いため, 放電痕の直径が大きくても数十 $\mu \mathrm{m}$ しかないことから考兄る と，そのときの放電柱の爆圧力が数 $100 \mathrm{MPa}$ にもなっている

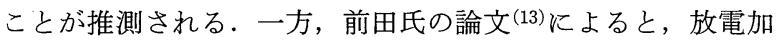
工圧力が金属材料の表面を塑性したり破壊したりするほど大き くなくても，最大值が数 $10 \mathrm{~kg} / \mathrm{mm}^{2}$ があると指摘された。な お，本文では極間に生じた衝撃力の測定法としては, 試片を載 せたロードセルで検出された電圧をアンプによって拡大してデ ータレコーダに記録し，校正線図によって換算する.

\section{3. 摇動加工による影響}

金属材料の放電加工では, 工具電極の摇動による放電加工特 性の改善が可能であることが知られている.その理由としては 型彫り放電加工のとき, 寄せ加工のため, 側面の極間距離が増 大し，加工屑の排出が改善できる．または電極の摇動によって 放電点拉よび加工屑の集中状態を減少できることなどによるも のと考劣られる.セラミックスは金属材料に比べ電気的抵抗が かなり高いため, 放電可能な極間距離が比較的小さく, 加工屑 の排出は困難と思われる. したがって, 工具電極の摇動による 放電加工特性の改善が期待される. Fig. 9 は電流 $I_{\mathrm{p}}=3 \mathrm{~A}$, パ ルス幅 $\tau_{\mathrm{p}}=100 \mu \mathrm{s}$ の条件で, 工具電極を摇動しながら放電し たとき，摇動距離が放電加工特性に及ぼす影響を示す．図中の 円形は通常の放電加工(無摇動の放電加工)によって得られた結 果を示す．これを基準として比べてみると，摇動距離が 0.5 $\mathrm{mm}$ の場合, 無摇動の放電加工より加工速度が $40 \%$ ほど増大 したが，表面あらさ，特に電極消耗率がかなり悪化した。 しか し, 摇動距離の増大に伴い, 加工速度の改善効果が少なくな

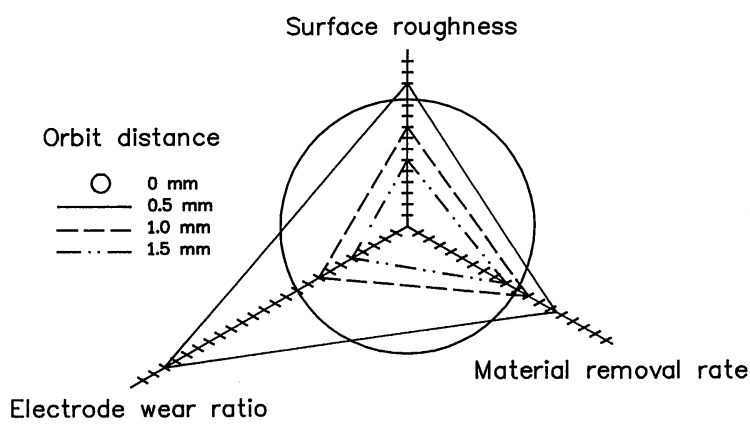

Fig. 9 Effect of orbit distance on the material removal rate, surface roughness and electrode wear ratio.
り, 表面あらさおよび電極消耗率の改善が顕著となる. 特に摇 動距離 $1.5 \mathrm{~mm}$ の場合では, 無摇動の放電加工に比べ, 加工速 度がほぼ同程度であるが，表面あらさおよび電極消耗率が約半 分と改善されたことがわかる.上述のことから，セラミックス の放電加工に抬いては, 工具電極を摇動しながらの放電加工法 が加工精度の改善にとって非常に有効な手段であることが確認 された.

\section{N. 結 言}

導電性アルミナ系セラミックス材料を放電加工するとき，異 なる極性の放電による加工特性への影響について調べた，得ら れた結果は次のようになる。

（1）逆極性放電加工後の表面あらさが正極性加工よりも大き くなる.

（2）微小電流の放電加工では，逆極性放電の加工速度が正極 性加工より大きいが，大電流で放電すると，逆極性加工の方が 反対に小さくなる。 また, 微小電流で放電する場合, 逆極性加 工の電極消耗率が小さいが, 大電流で放電すると, 正極性加工 の方が小さくなる.

（3）小パルス幅での逆極性放電加工の場合，極間に生じた衝 撃力が大きいため, 再凝固層が薄く, 亀裂も見当たらないのに 対し, 正極性加工の再凝固層が厚く残留し, またとの中に微細 亀裂が顕著に存在することが確認された。

（4）通常の放電加工に比べ，工具電極を摇動しながらの放電 加工は, 加工速度が大きく改善されたが，表面あらさ，特に電 極消耗率も増大する. しかし, 摇動距離を増大すると, 加工速 度が若干低下するが, 表面あらさおよび電極消耗率が大幅に改 善できる。

\section{文献}

（1）斎藤長男 : ファインセラミックスの精密加工, 工業調査 会, (1990), 227.

（2）斎藤長男, 毛利尚武：ファインセラミックスの放電加工 执よび超音波加工，電気加工技術，Vol. 13， No. 40 (1989), 18.

(3) 三宅雅也, 竹内久雄 : 放電可能なセラミックス, セラミ ックス, 21(1986), 719 .

(4) W. Konig, D. F. Dauw: Annals of the CIRP, 37 (1988), 623.

（5）向山芳世監修: 型彫・ワイヤ放電加工マニュアル，大河 出版, (1989), 154.

（6）佐藤敏一：特殊加工，養賢堂出版，(1981), 29.

（7）電気加工学会関西支部編：放電加工の理論と技術, 養賢 堂出版, (1972), 18.

（8）元木幹雄, 佐藤隆一, 橋口清人, 徳山赫淇 : 精密機械, 27 (1961), 193.

（9）木本保夫，田宮勝恒，平田勝己：日立造船技報, 28(1967), 81.

(10) 顔 炳華, 謝 福田: 軽金属, 42(1992), 645

（11）顔 炳華, 劉 弘松: 軽金属, 43(1993), 227.

(12) U. P. Singh, P. P. Miller and W. Urquhart: Proceeding of ISEM-9, (1989), 337.

（13）前田禎三 : 精密機械, 29 (1963), 432-435. 